Check for updates

The BMJ

fgodlee@bmj.com Follow Fiona on Twitter @fgodlee

Cite this as: $B M / 2021 ; 372: n 393$ http://dx.doi.org/10.1136/bmj.n393 Published: 11 February 2021

\title{
Covid 19: Two million deaths, so what went wrong?
}

\section{Fiona Godlee editor in chief}

Covid restrictions across Europe are bringing a stuttering end to a costly second wave and with it the recognition that the world will be living with SARS-CoV-2 in some form for years to come. In the UK, more than 100 ooo covid related deaths have been recorded on death certificates, ${ }^{1}$ more than 30 ooo of them in January alone, the second highest monthly death toll of the pandemic. With improved survival and lengthier hospital stays, pressure on the health service will continue even as infection rates fall, amplified by long covid ${ }^{2}$ and the ever growing backlog of non-covid care. ${ }^{3}$

What then are we to make of the UK prime minister's assertion that his government did everything it could? ${ }^{4}$ When governments fail to take responsibility for their actions and omissions, what routes are available to hold them to account? "Should these deaths be seen as 'social murder'?” asks Kamran Abbasi. ${ }^{5}$ Or failing that, as crimes against humanity, involuntary manslaughter, misconduct in public office, or criminal negligence? Politicians must be held to account by any constitutional means necessary.

And that's because politics has driven the pandemic's trajectory around the world. As Clare Wenham writes, governments that were willing to take the early hit of harsh restrictions are now reaping the benefits. ${ }^{6}$ Meanwhile, in other countries, "trying to appease both public health demands and the libertarian views of the free market has led not only to astronomical death tolls, such as in the US, UK, and Brazil, but to flailing economies," she writes.

Avoidance, delay, and mishandling have been compounded by a refusal to change course in the face of evidence and events. Even as case numbers fall and vaccines bring new hope, urgent action is needed to support self-isolation ${ }^{7}$ and make workplaces safer, especially for healthcare workers. We should not accept the harms they face in the line of duty, writes David Berger. ${ }^{9}$ New evidence of aerosol transmission and higher rates of seroconversion among non-ICU staff should prompt urgent action in the form of respiratory PPE and improved ventilation. ${ }^{10}$

Meanwhile it's vital that we find sources of hope. The phenomenal success of the vaccination programme is the most concrete, not only for people receiving it but for those delivering it. ${ }^{112}$ Evidence based calls to "build back fairer" 13 and to provide a universal basic income ${ }^{14}$ bring dreams of a 1948 moment, ${ }^{8}$ when, still struggling with the aftermath of war, our politicians found the energy to reconfigure society on fairer terms.
2 Alwan N. We must pay more attention to covid-19 morbidity in the second year of the pandemic. BMJ Opinion. 3 Feb 2021. https://blogs.bmi.com/bmi/2021/02/03/nisreen-alwan-we-must-pay-moreattention-to-covid-19-morbidity-in-the-second-year-of-the-pandemic.

3 lacobucci G. How is the pandemic affecting non-covid services?BMJ 2021;372:n215. doi: 10.1136/bmj.n215 pmid: 33483334

4 McIntyre N, Walker P, Duncan P, Booth R. "I'm deeply sorry": Boris Johnson faces questions over UK covid death toll. Guardian. 26 Jan 2021. https://www.theguardian.com/world/2021/jan/26/ons-figures-show-ukpassed-100000-covid-deaths-by-7-january.

5 Abbasi K. Covid-19: Social murder, they wrote-elected, unaccountable, and unrepentant. BMJ 2021;372:n314. doi: 10.1136/bmj.n314 pmid: 33536181

6 Wenham C. What went wrong in the global governance of covid-19?BMJ 2021;372:n303. doi: 10.1136/bmi.n303 pmid: 33536160

7 Stokel-Walker C. Covid-19: Why test and trace will fail without support for self-isolation. BMJ2021;372:n327. doi: 10.1136/bmj.n327 pmid: 33558221

8 lacobucci G. Jeremy Hunt: I was too slow to boost the NHS workforce-the government must, and can, act now. BM/2021;372.

9 Berger D. Up the line to death: covid-19 has revealed a mortal betrayal of the world's healthcare workers. BMJ Opinion. 29 Jan 2021. https://blogs.bmi.com/bmi/2021/01/29/up-the-line-to-death-covid-19-hasrevealed-a-mortal-betrayal-of-the-worlds-healthcare-workers.

10 Torjesen I. Covid-19: Risk of aerosol transmission to staff outside of intensive care is likely to be higher than predicted. BMJ 2021;372:n354. doi: 10.1136/bmj.n354 pmid: 33547056

11 A celebration of community collaboration-the vaccine "makers" give us hope. BMJ Opinion. 5 Feb 2021. https://blogs.bmj.com/bmj/2021/02/05/acelebration-of-community-collaboration-the-vaccine-makers-give-us-hope

12 Salisbury H. Helen Salisbury: Everyone wants to feel useful. BMJ 2021;372:n366. doi: 10.1136/bmi.n366 pmid: 33563591

13 Griffin S. Covid-19: Failure to control pandemic and inequalities made England worst affected in Europe, says report. BMI2020;371:m4842. doi: 10.1136/bmj.m4842 pmid: 33318131

14 Patel SB, Kariel J. Universal basic income and covid-19 pandemic. BMJ 2021;372:n193. doi: 10.1136/bmj.n193 pmid: 33500257

This article is made freely available for use in accordance with BMJ's website terms and conditions for the duration of the covid-19 pandemic or until otherwise determined by BMJ. You may use, download and print the article for any lawful, non-commercial purpose (including text and data mining) provided that all copyright notices and trade marks are retained. 